\title{
Does temporary geographical proximity predict learning? Knowledge dynamics in the Olympic Games
}

\author{
Self-archived post-print of:
}

Müller, Martin, and Allison Stewart. 2016. "Does Temporary Geographical Proximity Predict Learning? Knowledge Dynamics in the Olympic Games.” Regional Studies 50 (3): 377-90. https://doi.org/10.1080/00343404.2014.917168.

\author{
Martin Müller \\ Universität Zürich \\ Winterthurerstrasse 190 | 8057 Zürich | SWITZERLAND \\ martin@,martin-muller.net \\ www.martin-muller.net \\ Allison Stewart \\ University of Oxford
}




\section{Does temporary geographical proximity predict learning? Knowledge dynamics in the Olympic Games}

\section{Abstract}

Temporary geographical proximity in the form of face-to-face contact is commonly thought to enhance learning. In a sample of individuals $(n=294)$ involved in knowledge transfer in the Olympic Games, temporary geographical proximity emerges as a rather weak predictor of learning, although its explanatory value improves when coupled with organised proximity. This association disappears, however, when controlling for other predictors, suggesting that there is no unique effect of temporary geographical proximity on learning. Part of the effect of temporary geographical proximity is mediated through other variables, urging further research into the paths of mediation. Several practical implications for knowledge transfer in megaevents result.

Keywords: proximity, learning, knowledge management, mega-events, Olympic Games JEL codes: D83; L30; L83 


\section{Kann temporäre räumliche Nähe Lernprozesse vorhersagen? \\ Wissensdynamiken bei den Olympischen Spielen}

Abstract

Temporäre räumliche Nähe in Form von Face-to-Face-Kontakten gilt üblicherweise als Verstärker von Lernprozessen. In einer Stichprobe von 294 Individuen, die am Wissenstransfer bei der Organisation der Olympischen Spiele teilnehmen, besitzt temporäre räumliche Nähe nur einen geringen Erklärungsgehalt für Lernprozesse. Dieser nimmt etwas zu, wenn räumliche Nähe mit organisatorischer Nähe verbunden ist. Dieser Effekt lässt sich jedoch nicht mehr feststellen, wenn für andere Bestimmungsfaktoren in der Regressionsgleichung kontrolliert wird, so dass eine eindeutige Auswirkung von temporärer räumlicher Nähe auf Lernprozesse ausgeschlossen werden kann. Da ein Teil des Effekts von temporärer räumlicher Nähe durch Vermittlungsvariablen entsteht, scheint weitere Forschung in die Vermittlungspfade vielversprechend. Es resultieren einige praktische Implikationen für den Wissenstransfer bei Großveranstaltungen.

Keywords: räumliche Nähe, Lernprozesse, Wissensmanagement, Großveranstaltungen, Olympische Spiele 


\section{Introduction}

The extent to which geographical proximity matters in the exchange of knowledge is a hotly debated issue. Three positions exist: one argues that geographical proximity is essential for the transfer of knowledge, since it allows frequent face-to-face contact, which, in turn, promotes the exchange of tacit knowledge (MORGAN, 2004; STORPER and VENABLES, 2004). This is the argument at the heart of concepts such as learning regions and innovative milieux and drives policies to promote the spatial agglomeration of firms in clusters to spark cooperation and innovation and exchange types of knowledge that are embodied and contextdependent (AUDRETSCH and FELDMAN, 2003; PORTER, 2000; SAXENIAN, 1996). It also is evident in the literature on innovation and learning within organisations, where face-toface interaction is considered crucial in tacit learning and the development of knowing practices (FAULCONBRIDGE, 2006; GERTLER, 2003; JONES, 2007).

The second position maintains that with the development of information and communication technologies (ICT), knowledge exchange, even of tacit knowledge, can now occur over long distances through intranet platforms, online workspaces, chat rooms, discussion fora and social software (AMIN and COHENDET, 2004). It has been argued that ICT can facilitate the emergence of communities of practice, which share a common set of situations, problems, languages and codes, despite a lack of face-to-face contact (WENGER, 1998). As a consequence, this suggests a departure from the territorial model of learning towards new modes of conceptualising translocal relationships (AMIN and COHENDET, 2004; IBERT, 2010).

Recently, there has also evolved an intermediate position, which underscores the importance of temporary geographical proximity: while maintaining the importance of face-to-face contact, proponents argue that there is no need for permanent geographical proximity, or colocation, since short- or medium-term visits can also serve the purpose of exchanging relevant 
knowledge (TORRE, 2008). Such short- or medium-term visits are dependent on mobility (LARSEN et al., 2006) and can take place at fairs and trade shows, workshops, conferences and so on that allow for regular interaction (e.g. BATHELT and SCHULDT, 2008; FAULCONBRIDGE et al., 2009). The result are ephemeral interactions that lead to the emergence of differentiated forms of knowledge networks with varying degrees of coherence, but in general with weaker ties than those assumed in the literature on clusters and communities of practice (GRABHER, 2004a, b). The proposed significance of temporary proximity tallies with the claim that successful learning is a function of both proximate and distant relations (OINAS, 1999).

Intervening in this debate, the present article seeks to expand on this third perspective to explore the significance of temporary geographical proximity for individual learning. It adopts a quantitative approach, extracting relevant propositions and variables from the literature, operationalising them and feeding them into regression models. In so doing, it complements work on the role of different types of proximities in interpersonal learning, which often tends to have a qualitative focus. A quantitative approach has the advantage of being able to formalise and test hypotheses statistically, while, at the same time, inevitably reducing the complexity of learning interactions to a number of variables. The article examines four major propositions that emerge from the literature:

(P1) Temporary geographical proximity needs to be coupled with organised proximity to become a significant predictor of learning.

(P2.1) Temporary geographical proximity is positively associated with both document learning and informal learning.

(P2.2) Document learning is positively associated with informal learning and vice versa. 
(P3) Temporary geographical proximity has explanatory value for learning over and above other predictors.

Addressing the comparative lack of empirical research on individual knowledge relationships vis-à-vis firm-level data in the research on the spatial dimensions of learning (cf. GRABHER and IBERT, 2006; HASSINK and KLAERDING, 2012; HUBER, 2012b; RUTTEN and BOEKEMA, 2012), our study draws on a dataset of individuals ( $\mathrm{n}=294)$ working in the Organising Committees of the Olympic Games of London 2012, Sochi 2014 and Rio de Janeiro 2016. In light of the massive growth of project-based forms of organising in recent years and the geographical dispersion and flexible geometries of personal networks that characterise them (GRABHER, 2002), the Olympic Games are a suitable example for investigating the relationship of temporary geographical proximity and learning. The challenge of organising what is arguably the most complex mega-event in the world in a different location, with a short deadline, a diverse range of tasks and a different team of staff every two years marks Organising Committees as learning-intensive organisations (HALBWIRTH and TOOHEY 2001; MÜLLER 2014; PARENT et al, 2014).

\section{Grounding the propositions}

\subsection{Temporary geographical proximity and organised proximity}

Contesting the traditional thesis that permanent geographical proximity and the resulting opportunities for regular face-to-face contact are crucial ingredients for knowledge sharing, recent literature has drawn attention to the role of temporary geographical proximity (TORRE, 2008; TORRE and RALLET, 2005). With the increasing mobility of workers and managers alike, obtaining embodied face-to-face contact, at least for some time, may not require the co-location of organisations in space (AMIN and COHENDET, 2005; BATHELT and SCHULDT, 2010; FAULCONBRIDGE et al., 2009). In fact, the boom in business travel, 
points to the conclusion that transient face-to-face contact maintained through individual mobility is a defining feature, both for large transnational corporations (JONES, 2007) and for smaller firms (WICKHAM and VECCHI, 2008). Among others, it serves to promote innovation, the sharing of tacit knowledge and the development of knowledge practices. To this end, permanent geographical proximity may not be necessary, since face-to-face contact has been found to be critical only for some phases of a project or innovation process (HUBER, 2012a; TORRE and RALLET, 2005).

At the same time, temporary proximity also provides a way of navigating the dual challenge of being here and there, i.e. of maintaining both local and global relations to promote the acquisition of new knowledge (BATHELT et al., 2004; WINK, 2008). It offers the flexibility to explore potential new links, while avoiding the high sunk costs that are associated with localisation decisions (RYCHEN and ZIMMERMANN, 2008). Moreover, temporary proximity, it has been stressed, might also circumvent the detrimental side-effects of permanent geographical proximity, such as rivalry or lock-in, which may lead to an overreliance on local relations at the expense of global ties and hamstring the creation of new knowledge (e.g. BATHELT et al., 2004; BOSCHMA, 2005; TORRE and RALLET, 2005). In short, this position proposes that temporary geographical proximity could deliver similar or superior benefits for knowledge exchange and learning as have been claimed for permanent territorial co-location.

Such temporary encounters are prominent in projects, where collaboration between members in project teams is for a limited period of time and teams are often changed for new projects. This particular situation leads to the emergence of various forms of social ties that are more ephemeral than under permanent geographical co-location (GRABHER, 2004a, b). Ties that are latent now might be re-activated later on, personal networks often outlast particular projects and occasional face-to-face meetings are sufficient to allow for the flow and creation 
of knowledge. With the rise of project modes of organisation (MIDLER, 1995), temporary geographical proximity is thus becoming more common and important vis-à-vis the long-term relationships that are often associated with permanent geographical proximity (GRABHER, 2002).

The importance of people's mobility for establishing temporary proximity underscores the need for an analytical shift from firm-level to individual-level analysis: no longer can knowledge exchange be gauged from the proximity of firms, but it must be analysed by looking at the travelling individuals and the transient proximities they establish in their worklives. This focus on the individual is all the more pertinent when examining temporary organisations and projects, in which knowledge retention and circulation is more dependent on the individual than on the organisation as a whole (ASHEIM, 2002; EKSTEDT et al., 1999). It urges us to supplement studies on firm-level interaction, which dominate work on territorial innovation models, with those on spatial aspects of individual-level learning (HASSINK and KLAERDING, 2012; HUBER, 2012a; MALMBERG and POWER, 2005; RUTTEN and BOEKEMA, 2012).

Recent studies, however, have also emphasised that geographical proximity, whether permanent or temporary, is not a sufficient condition for learning (BOSCHMA, 2005; GLÜCKLER and RIES, 2012; TORRE and RALLET, 2005). In addition to the mere 'being there', conditions need to be such that ties through which knowledge can be exchanged are forged, rather than hoping for their emergence out of thin air through mere physical copresence. Transfer of knowledge thus also rests on the "capacity to coordinate the exchange of complementary pieces of knowledge owned by a variety of actors within and between organizations" (BOSCHMA, 2005). Some authors speak of the necessity of "relational proximity" (e.g. AMIN and COHENDET, 2004; GERTLER, 2003; IBERT, 2010) and the French School of Proximity Dynamics treats this aspect under the label of "organised 
proximity", i.e. the coordination and control of interaction between members of one or several organisations that creates and channels knowledge flows (TORRE, 2008; TORRE and RALLET, 2005). An effective degree of organised proximity is often found in loosely coupled networks with weak ties between autonomous actors which enable coordination but circumvent lock-ins (GRABHER and STARK, 1997). Such networks can emerge, for example, through interventions for knowledge transfer which aim at establishing the communication channels to absorb new knowledge as well as recirculate, apply and recombine it (GLÜCKLER, 2008). In the first proposition for our analysis, we thus seek to test the role of temporary geographical proximity, with and without coupling with organised proximity:

(P1) Temporary geographical proximity needs to be coupled with organised proximity to become a significant predictor of learning.

\subsection{Tacit and explicit knowledge and learning}

Geographical proximity, both temporary and permanent, and the attendant face-to-face contact have been considered to be more important for the sharing of tacit rather than explicit knowledge (BATHELT et al., 2004; MACKINNON et al., 2002). Codified in manuals, books, guidelines and other documents, explicit knowledge is commonly assumed to face fewer barriers in circulation and be appropriated in a more straightforward fashion through documents of various sorts (MASKELL and MALMBERG, 1999; NONAKA, 1994). Tacit knowledge, by contrast, is thought to typically require face-to-face interaction, often in small groups and on a repeat basis, to be transmitted and shared, due to its being rooted in direct experience and via "the informal take-up of learned behaviour and procedures" (HOWELLS, 2002: 872; see also JONES, 2007; MORGAN, 2004; NONAKA, 1994; STORPER and VENABLES, 2004). 
More recently, however, authors have challenged the distinction between tacit and explicit forms of knowledge as simplistic and flawed (e.g. AMIN and COHENDET, 2005; IBERT, 2007; MEUSBURGER, 2009; NONAKA and VON KROGH, 2009). According to this position, tacit knowing is, to a greater or lesser degree, inherent to all forms of knowledge and cannot be separated from explicit knowledge. The interpretation of a document, although ostensibly codified, often requires much tacit knowledge for instance about its origin, its purpose, its author or the codes used. Different readers of a document will interpret it in different ways such that the knowledge transmitted is not uniform. Explicit knowledge is thus never independent of its context, but embedded in a wide web of relationships: it "only becomes meaningful in relation to a distinct social practice” (IBERT, 2007: 105).

Giving up the distinction between explicit and tacit forms of knowledge has important implications for the role of geographical proximity. If tacit elements are part of all forms of knowledge, it would be reasonable to expect that geographical proximity also benefits the sharing of knowledge through documents. Face-to-face interaction often reduces the ambiguity of new explicit knowledge and makes it easier to apply (MASKELL and MALMBERG, 1999; NONAKA and VON KROGH, 2009) - a position also held by Michael Polanyi (1966), who introduced the concepts of tacit and explicit knowledge in the first place. The second proposition engages with these debates. It examines two forms of interaction for learning: document learning, i.e. learning occurring primarily through the consultation and study of documents such as manuals, guidelines, plans or reports, and informal learning, i.e. learning occurring primarily through informal exchange that centres on embodied, personal know-how and tricks of the trade. It does not assume, however, that these two interactions are separate. Instead it seeks to test whether informal learning is also a predictor for document learning (as would have to be expected according to the more recent debates) and vice versa, and whether temporary geographical proximity predicts only informal learning (the 
conventional view) or both face-to-face and document learning (the more recent view). Hence we derive the following two related propositions:

(P2.1) Temporary geographical proximity is positively associated with both document learning and informal learning.

(P2.2) Document learning is positively associated with informal learning and vice versa.

\subsection{The unique contribution of geographical proximity for explaining learning}

Boschma (2005) has pointed out the need for empirical studies that isolate the unique effect of geographical proximity on learning through controlling for the influence of other variables. This call is all the more pertinent considering that previous research has found contradictory evidence: while some studies show that the predictive power of permanent geographical proximity disappears when applying controls (e.g. BRESCHI and LISSONI, 2003), others find that it remains a significant predictor (e.g. BROEKEL and BOSCHMA, 2012). Much of this also depends on the precise delimitation of the variables involved. In particular, it has been shown that permanent geographical proximity may have an indirect effect on learning that works through other variables as mediators (e.g. PONDS et al., 2007; SINGH, 2005; WATSON, 2008).

In an attempt to isolate the unique effect of temporary geographical proximity, we introduced a number of control variables in our study that are relevant to individual-level learning. We derived these chiefly from the literature on organizational knowledge transfer (e.g. CROSS and SPROULL, 2004; LEVIN and CROSS, 2004; MEUSBURGER 2009; SIMONIN, 1999, 2004; SZULANSKI et al., 2004; VAN WIJK et al., 2008), but also constructed some on our own, where we assumed they may have an impact in the specific setting of the Olympic Games (see Table 1 for control variables). 
- Document usage refers to the consultation of documents such as books, manuals, reports or statistics. As such, it controls for the frequency of respondents' exposure and interaction with codified information.

- Event experience measured whether a respondent had worked previously for the Olympic Games or other international large-scale events to capture how this might affect learning. The assumption here is that personal knowledge networks, developed through work at multiple events, could represent major sources of knowledge, as is common for projects (GRABHER, 2004a).

- Motivation: Individual motivation and openness to learning are crucial preconditions for the assimilation of knowledge (MEUSBURGER 2009; OSTERLOH and FREY, 2000; SZULANSKI et al., 2004). This variable controls for the motivation to participate in knowledge transfer, i.e. accept knowledge from outside and share knowledge with others.

- Knowledge sharing environment: Individual motivation may not be sufficient for learning if the organisational setting is not conducive to it (DAVENPORT and PRUSAK, 2000). Knowledge sharing environment measures to what degree the organisation encourages and provides time and opportunities for knowledge sharing.

- $\quad$ Prior expertise adjusts for the presence of existing knowledge, which can have ambiguous effects. On the one hand, it can impede learning, because experts do not find additional knowledge as useful as novices and bodies of knowledge are too similar to create meaningful learning effects (LEVIN and CROSS, 2004). On the other hand, it can also speed up learning, because it makes it easier to bridge knowledge gaps and integrate new elements into existing bodies of knowledge - a phenomenon known as absorptive capacity in the management literature (COHEN and LEVINTHAL, 1990; NOOTEBOOM, 2000). 
- Knowledge perishability: Knowledge often has a certain shelf-life and its validity expires or decreases over time. This is particularly true for sectors with rapid innovation cycles or for short-lived projects such as the Olympic Games. Knowledge perishability is a temporal attribute of knowledge and addresses to what degree knowledge quickly gets out of date and needs to be refreshed and updated (HOLSAPPLE, 2003).

- $\quad$ Actionable relevance: Knowledge that helps 'making progress on relatively short-term projects' (CROSS and SPROULL, 2004) is considered to have actionable relevance. It can be used without much further processing and is directly applicable to assignments.

If the effect of temporary geographical proximity for learning is unique, it must remain when controlling for these other variables. Thus we propose:

(P3) Temporary geographical proximity has explanatory value for learning over and above other predictors.

\section{Learning and the Olympic Games}

The dispersed organisation of successive Olympic Games represents a particularly suitable case for examining learning across sites through temporary geographical proximity. In 2012 for example, the IOC, based in Switzerland, had to oversee and coordinate the simultaneous preparation for the Olympic Games to be held in London (England) in 2012, Sochi (Russia) in 2014, Rio de Janeiro (Brazil) in 2016 and Pyeongchang (South Korea) in 2018. In each of the host cities, a so-called Organising Committee of the Olympic Games (OCOG) is in charge of the operational organisation of the Olympic Games. With their comparatively short-lived nature, task orientation and fixed delivery deadlines, the mixture of close and distant interactions and the high importance of learning in short time, OCOGs exhibit many of the characteristics that have recently received increasing attention under the conceptual umbrella 
of project ecologies (GRABHER, 2002, 2004a, b; IBERT 2004) and temporary organisations (ASHEIM, 2002; EKSTEDT et al., 1999).

The vast majority of requirements that OCOGs need to meet in the organisation of the Olympic Games remain similar for each edition of the Games, as do the major milestones and deliverables for this mega-project. At the same time, when an OCOG is first established, its staff face the daunting task of having to organise the largest and most complex sports event in the world, a project most never have previously been involved in, since the Games are traditionally held in different parts of the world. What adds to the challenge is the tight time frame and the massive scale and complexity of the Olympic Games: within seven years and with an operational budget of typically between USD 1 and 2 billion, an OCOG grows to employ several thousand employees and tens of thousands of volunteers during Games time. Moreover, the functional areas to be covered in the organisation of an Olympic Games require highly diverse skills and knowledge of the state of the art. To accomplish the tasks of an OCOG demands expertise ranging from information systems, catering, construction and venue management to language services, logistics, transport management and diplomatic protocol. This situation underscores the need and indeed imperative of learning across a wide range of fields of expertise, in a short term and across multiple sites.

As in most project-based organisations, knowledge in OCOGs is mostly embodied in individuals who provide diverse know-how and problem-solving skills on an ad hoc basis, resembling what Mintzberg (1980; see also LAM, 2000) has called an 'operating adhocracy'. As in most projects (EKSTEDT et al., 1999; GRABHER, 2004b), the administrative function is fused with the operating task and coordination happens mostly through direct interaction. Just like operating adhocracies, OCOGs are fast-moving and fluid, and the speed of learning is crucial for their success. At the same time, however, the orientation towards problemsolving and deadlines, typical for projects (IBERT, 2004), promotes one-off learning. 
Information that is easily available and required to fulfil a specific task at hand is readily absorbed. But under time pressure, knowledge repositories are often not perused and, as a consequence, solutions for problems are reinvented instead of making use of existing information from elsewhere (SCHINDLER and EPPLER, 2003) - a phenomenon known as the not-invented-here syndrome (KATZ and ALLEN, 1982). In addition, after an Olympic Games knowledge for a long time was not stored or systematised in a coherent fashion, thus making it inaccessible for future Games organisers and compounding the problem of learning.

In order to counteract this amnesia and structure the sharing of knowledge, the IOC introduced a knowledge management system towards at the beginning of the $2000 \mathrm{~s}$ (FRAWLEY and TOOHEY, 2009; HALBWIRTH and TOOHEY 2001; PARENT et al, 2014). This was partly also a response to the increasing size and complexity of these events and the associated risks of mismanagement (FLYVBJERG and STEWART, 2012; FRAWLEY and ADAIR, 2013; JENNINGS, 2012). The IOC started a document management platform, which hosts relevant documents from previous editions of the Olympic Games and from the IOC online to facilitate access and circulation. It has also compiled manuals for the most important areas of the organisation of the Olympic Games, detailing the requirements of organising the event and how to achieve them. In addition to the circulation of documents, the IOC also organises short-term knowledge sharing events, for example during workshops or debriefings, where members from the different OCOGs meet face-to-face, often for the first time, with the express purpose of exchanging knowledge on their respective tasks. These events establish organised proximity through weak ties (BOSCHMA, 2005): interactions are coordinated, but at the same time the interacting individuals remain members of different, autonomous entities which are not in a competitive relationship with each other. Through these temporary encounters and circulating documents, knowledge is sought to be mobilised across multiple locations in order to enable successful action in the preparation of the Olympic Games (KASSENS-NOOR 2013; MÜLLER 2014). 


\section{Research design}

\subsection{Variable measurement and model specification}

Variable operationalisation and measurement are documented in Table 1. Wherever possible we drew on established constructs from the literature on learning and knowledge transfer (see column: sources). Learning acted as the dependent variable and we distinguished between two forms of learning interaction, described in section 2.2: document learning, occurring primarily through the consultation and study of documents such as manuals, guidelines, plans or reports, and informal learning, occurring primarily through informal exchange that centres on embodied, personal know-how and tricks of the trade.

Face-to-face contact and face-to-face intervention were specified as independent variables (see Table 1). Face-to-face contact expressed our definition of temporary geographical proximity, following Torre (2008). Face-to-face intervention was used to measure temporary geographical proximity coupled with organised proximity (TORRE and RALLET, 2005) in the form of coordinated knowledge transfer measures to stimulate face-to-face knowledge transfer and interactions between individuals. Seven predictors were included as controls, following on from the considerations in section 2.3. In order to control for differences between the three OCOGs that are not reflected in the independent variables, we introduced dummies.

Insert Table 1 here

We specified four separate multiple regression models to test the four propositions (Table 3). Model 1 included face-to-face contact as the only variable to test for its role as a predictor of 
each of the two forms of learning interactions (P1). Model 2 added face-to-face interventions, thus testing for the significance of the coupling of temporary geographical and organised proximity (P1; P2.1). Model 3 entered the respective other learning interaction as a predictor to examine the role of informal learning for predicting document learning and vice versa (P2.2). Model 4 tested whether temporary geographical proximity retained its effect on learning when controlling for other known predictors (P3). All models were also fitted with squared terms for the independent variables, document usage and prior expertise to test for curvilinear, bell-shaped relationships between these variables and learning. To this end, variables were centred through subtracting the mean before squaring them in order to avoid high multicollinearity.

\subsection{Sample}

A questionnaire containing the relevant items was hosted on an online survey platform. A pretest with 12 participants was conducted for instrument validation and to check for technical errors. Invitations to participate in the survey were sent out to all owners of e-mail addresses of the respective domains of the London, Sochi and Rio de Janeiro OCOGs (henceforth London 2012, Sochi 2014 and Rio 2016), followed by a reminder about two weeks after the initial invitation. After data clean-up, a total of 417 cases remained, 144 from London 2012, 235 from Sochi 2014 and 38 from Rio 2016. This corresponds to a total response rate of about 21\%, with about 11\% for London 2012, 39\% for Sochi 2014 and 42\% for Rio 2016.

$71 \%$ of respondents (294) reported exposure to at least one type of learning interaction: $66 \%$ (273) with document learning, 43\% (179) with informal learning and 38\% (158) with learning through both mechanisms. These 294 respondents formed the basis of the sample $(\mathrm{N}=294)$. $34 \%$ (101) of respondents from the final sample were from London 2012, 55\% (163) from Sochi 2014 and 10\% (30) from Rio 2016. The respondents included a broad sample of staff with different levels of seniority, lengths of service and from more than 40 different 
functional areas in the OCOGs. $60.2 \%$ had worked for their OCOGs for less than 12 months, underscoring the dynamic nature of these organisations. Mean length of work experience in the current field (including previous jobs) was 8.5 years. A bivariate correlation analysis revealed that seniority and job experience were not associated with either of the two learning interactions, thus allaying concerns about the potential influence of a selection bias. Length of service had a weak positive correlation with informal learning and we thus included it as a control variable in Model 4.

\subsection{Data preparation}

Before analysis, multi-item constructs were tested for internal consistency. As documented in Table 1, Cronbach's $\alpha$ as a measure for internal consistency yielded values of 0.65 or above, which is a common cut-off for constructs with few items (NUNNALY, 1978). The construct for perishability of knowledge received through document learning was below this cut-off and thus dropped from subsequent analysis. To check whether the variables met the requirements for OLS regression analysis, we conducted tests for distribution and multicollinearity.

Skewness and kurtosis were within the bounds of $[-2 ;+2]$ for all variables, with the exception of document learning, which had a weak positive kurtosis of 2.5. No multicollinearity was found, with the variance inflation factor (VIF) well below the threshold value of 4 . No multivariate outliers (Mahalanobis distance with $\mathrm{p}<0.001$ for the $\chi^{2}$ value) were identified.

\section{Results}

\subsection{Descriptive characteristics}

Means of learning on a 5-point Likert scale were 3.54 for document learning, 3.60 for informal learning and 3.57 as the mean for those who had had exposure to both interactions (Table 2). T-tests did not indicate a significant difference, suggesting that learning occurs to the same extent through document and through informal interaction and that being exposed to 
both forms of interaction does not increase learning. $72 \%$ of the sample indicated having had some face-to-face contact with people from other OCOGs or the IOC. The median score for the frequency of face-to-face contact is significantly higher for those who had exposure to both learning interactions or informal learning only as compared to those who were exposed to document learning only $(\mathrm{t}=5.76, \mathrm{p}<0.001$ and $\mathrm{t}=4.21, \mathrm{p}<0.001)$. A similar pattern holds true for face-to-face interventions, whereas there is no statistical difference in the degree of exposure to document usage between the groups.

Insert Table 2 here

As for the control variables, the sample showed $41 \%$ of respondents had previous large-scale event experience (London 2012: 42\%, Sochi 2014: 39\%, Rio 2016: 55\%). 13\% of the sample had worked for previous OCOGs, however this percentage varied considerably between the three OCOGs in the sample: while $23 \%$ of respondents indicated previous OCOG experience for London 2012, the share was 8\% for Sochi 2014 and just 3\% for Rio 2016.

Recipient motivation and the perceived presence of an organisational environment conducive to knowledge sharing received high scores across the board, with no significant differences between the groups. Prior expertise and the actionable relevance of the knowledge transferred were rated medium-high, with significantly higher scores for the informal learning interaction. The perishability of the knowledge acquired through informal learning was perceived as medium $(\mathrm{M}=2.86)$.

\subsection{Regression analysis}

The regression coefficients for Model 1 in Table 3 indicate that face-to-face contact was significant but contributed little to explaining variance in informal learning and nothing in 
document learning. This result was robust if we re-specified face-to-face contact as a dichotomous variable: those respondents with no face-to-face contact had somewhat lower informal learning scores than those with face-to-face contact $\left(\mathrm{M}_{\mathrm{no} \text { F2F }}\right.$ contact $=3.43 \mathrm{vs}$. $\mathrm{M}_{\mathrm{F} 2 \mathrm{~F}}$ contact $=3.63 ; \mathrm{t}=1.81, \mathrm{p}=0.07)$, but this difference disappeared for document learning $\left(\mathrm{M}_{\mathrm{no}} \mathrm{F} 2 \mathrm{~F}\right.$ contact $=3.50$ vs. $\left.\mathrm{M}_{\mathrm{F} 2 \mathrm{~F} \text { contact }}=3.55 ; \mathrm{t}=0.66, \mathrm{p}=0.51\right)$. Temporary geographical proximity per se is thus only a weak predictor of learning.

The situation changed somewhat, when we added exposure to targeted face-to-face interventions to the model, thus combining temporary geographical proximity with organised proximity (Model 2). The variable entered the regression equation for informal learning as a significant predictor and improved $\mathrm{R}^{2}$ to $5 \%$, but made the effect of simple face-to-face contact disappear. There was no similar effect, however, for document learning. In short, temporary geographical proximity as such was slightly associated with higher informal learning, even more so when coupled with organised proximity, thus providing validation for (P1), though in both cases the percentage of variance explained remained rather low. It did not have an effect on document learning, however, leading us to reject (P2.1).

Insert Table 3 here

Including informal learning to predict document learning and vice versa produced significant and strong effects. $\mathrm{R}^{2}$ values improved to $14 \%$ and $10 \%$ respectively. This result lends support to (P2.2), suggesting that informal learning indeed enhances document learning and vice versa. 
Adding the control variables to the regression model (Model 4) resulted in a large improvement of model fit $\left(\mathrm{R}^{2}=0.41\right.$ for document learning and $\mathrm{R}^{2}=0.36$ for informal learning) and revealed the actionable relevance of knowledge as the most important predictor for both interactions. In the case of informal learning, face-to-face interventions dropped out of the equation as a significant variable. Recipient motivation and knowledge sharing environment emerged as significant but rather weak predictors in both cases, as did the perishability of knowledge for informal learning and the frequency of document usage for document learning. Except for perishability, all signs of the coefficients pointed in the expected direction. The association of temporary geographical proximity with learning, even when coupled with organisational proximity, is thus not robust to the inclusion of control variables and consequently $(\mathrm{P} 3)$ needs to be rejected.

When estimating all models with the squared terms for the independent variables, document usage and prior expertise, none of them contributed to a meaningful improvement of $\mathrm{R}^{2}$ $(\Delta<0.01)$. Curvilinear relationships thus do not seem to provide a better estimation of the variance in learning and since coefficients changed only marginally, if at all, the results are not reported.

\subsection{Exploring mediated effects of proximities}

An analysis of bivariate correlations revealed a significant correlation between face-to-face interventions and actionable relevance $(\mathrm{r}=0.33, \mathrm{p}<0.01)$ and between face-to-face contact and actionable relevance $(\mathrm{r}=0.24, \mathrm{p}<0.01)$ for the case of informal learning. This result would suggest that actionable relevance mediates the association between temporary geographical and organised proximity as independent variables and informal learning as the dependent variable. To test for this, we conducted an exploratory test for mediation using an inference procedure with bootstrapping (PREACHER and HAYES, 2004). The test indicated a significant indirect effect $(p<0.01)$ both for face-to-face contact (effect size $a b=0.05)$ and 
for face-to-face interventions $(a b=0.09)$. The ratio of the indirect effect to the total effect was $84 \%$ for face-to-face contact and $59 \%$ for face-to-face intervention, suggesting the presence of considerable mediation for the case of informal learning. When including the remaining control variables, the effect of face-to-face contact became insignificant, but the effect of face-to-face interventions remained significant. No such effects, however, were found for document learning. There is thus provisional evidence for a mediated effect of temporary geographical proximity, coupled with organised proximity, on learning. In other words, temporary geographical proximity may not have a direct effect on learning but it may influence other variables that have a direct effect.

\section{Discussion and Conclusion}

Does temporary geographical proximity predict learning? Attempting to isolate the effect of temporary geographical proximity statistically, this manuscript has set out to contribute towards an answer to this question. For this purpose, it has selected the organisation of the Olympic Games whose geographical dispersion - preventing permanent co-location -, high demand for knowledge, and coupling of temporary geographical proximity and organised proximity make for a good case for examining the association of temporary geographical proximity with learning. Working at the level of the individual, the paper has heeded the call for more research on individuals as the social agents of learning and their interactions in space (HASSINK and KLAERDING, 2012; HUBER, 2012a; RUTTEN and BOEKEMA, 2012).

All in all, there is weak evidence that temporary geographical proximity per se predicts interpersonal learning. When coupled with organised proximity, it acts as a somewhat better predictor for learning, but even then this is only true for informal learning interactions, not for document learning interactions. When controlling for other predictors, the effect of temporary geographical proximity, with and without organised proximity, becomes insignificant, 
suggesting that it does not have a direct effect on learning. These findings tally with research on innovative performance at the firm level (KNOBEN and OERLEMANS, 2012) and knowledge spill-overs measured on the basis of patent citations (BRESCHI and LISSONI, 2009).

Instead, the actionable relevance of the knowledge received emerges as the strongest explanatory variable for learning. We suspect that a major reason for the dominance of actionable relevance over proximity and other variables is to be found in the task- and deadline-orientation of projects (AJMAL and KOSKINEN, 2008; IBERT, 2004). In general, in the close succession of deadlines there is little time for extensive processes of adaptation, modification and deliberation of knowledge and the cumulative building up of a knowledge stock. For this reason, a preference for out-of-the-box solutions with immediate applicability can be observed. This situation seems to be the primary driver for the role of actionable relevance as a strong predictor in this specific context. Neither prior expertise, which could function as a measure of cognitive proximity, nor event experience, which shares similarities with definitions of social proximity, were revealed to be significant predictors. Similar to other recent studies (BROEKEL and BOSCHMA, 2012), all of the observed associations of proximity with learning are better fitted with linear than with quadratic functions, suggesting the absence of bell-shaped curves.

The coupling of temporary geographical with organised proximity to enable learning concurs with the propositions of Torre and other authors (e.g. FILIPPI and TORRE, 2003; TORRE, 2008; TORRE and RALLET, 2005): in addition to just bringing people together, this face-toface contact is more productive if the resulting interaction is structured and targeted in such a way as to facilitate knowledge exchange through the development of shared standards of communication, understandings of tasks and concepts and interpretative schemes. Overall, however, the total effect of proximity in our case was rather weak, when compared to other 
predictors such as actionable relevance. Given that temporary organisations such as the Organising Committees of the Olympic Games often lack a coherent, structured knowledge base in the own organisation and have little previous experience with this complex task, we would have expected a greater importance of face-to-face contact for learning. This is even more so considering that the Organising Committees are temporary operating adhocracies, where knowledge is typically embodied in individuals, and forging and maintaining personal networks plays a crucial role for exchanging knowledge (EKSTEDT et al., 1999; GRABHER, 2002). To be sure, the documentation that is provided on the part of the IOC structures and conserves some knowledge and, as our data show, provides opportunities for learning. At the same time, however, this codified knowledge has clear limitations and its efficient use requires the ability to read between the lines and understand the contingency of its creation; in other words, it is enhanced by informal learning interactions, as our results show. This is also true for the reverse, i.e. informal learning interactions benefit from learning through the study of documents.

While the unique direct effect of temporary geographical proximity on learning is rather negligible for our case, we believe that a promising avenue for future research would be to centre on the mediated effects of proximity. As our exploratory analysis in section 5.3 indicated, in order for knowledge to obtain actionable relevance and thus result in learning, temporary geographical proximity coupled with organised proximity seems to have a role to play. This result suggests that its effect on learning is more likely indirect, shaping other constructs and stimulating other types of proximities (cf. BOSCHMA, 2005; HOWELLS, 2002). The question of how the effect of geographical proximity comes to be should thus interest us just as much, or perhaps even more, as the question of what its effect is, which has taken centre stage so far. Consequently, future studies should put an emphasis on tracing the mechanisms, modelling the paths and testing potential intervening constructs through which geographical proximity, whether temporary or permanent, is associated with learning. As far 
as quantitative research is concerned, this observation would suggest an emphasis on statistical methods such as Structural Equation Modelling and mediation analysis for the inferential testing of these indirect effects.

\section{Practical Implications}

What, then, are the practical implications of our analysis for sports event management? Above all, it suggests to tailor knowledge management so as to transfer knowledge with immediate actionable relevance to a problem at hand. Generic templates, unstructured document repositories or broad workshops are unlikely to meet that task. Such tailoring is far from facile, because it requires information about the changing knowledge needs at a different points in time, the organizational context as well as the varying cultural settings in which large-scale sports events take place. It is a truism that different contexts ask for different solutions. As a consequence, the call for making knowledge actionable and relevant should not be interpreted as a plea for delivering ready-made solutions but rather for knowledge management that addresses and outlines the scope of the relevant problem and the possible courses of action.

The data also show that there is equal learning through both document and informal learning. This result suggests that none of these two interactions is per se more or less important. It would thus be wrong to fetishise face-to-face contact as the prime or privileged way of facilitating learning. Instead, our analysis shows that document and informal learning complement each other. For better understanding documents, it is important to have informal talks and exchange, for example to be able to read between the lines. And for making the best of informal talks and exchange, it is helpful to have studied documents, for example in order to ask the right questions or better make sense of what is being said. As sports organisations 
develop knowledge management tools, it is thus important to address both document and informal learning, ideally in ways that make them interact with each other.

One major result of our analysis is that temporary geographical proximity of individuals per se does not directly predict learning. This does not mean, however, that face-to-face contact is expendable. Rather, we have found evidence that face-to-face contact shapes other important factors, such as the actionable relevance of knowledge, and thus has an indirect effect on learning. In other studies, it has also been found to cement trust and thus increase learning (e.g. STORPER and VENABLES, 2004). Also, face-to-face contact seems to be more effective when embedded into structured activities, such as debriefings or workshops, that help to orient participants towards each other and coordinate interaction. The bottom line is that face-to-face contact remains crucial for learning, but there is still need for further research how exactly. This said, it is crucial not to lose sight of other factors that are associated with learning outcomes. The recipients' motivation for learning and the conduciveness of the organizational environment to knowledge sharing have also emerged as important parameters. Thus, knowledge management in sports events needs to work on a number of fronts if it wants to enhance learning.

Acknowledgement: This research has benefited from funding from the Olympic Studies Centre in Lausanne and from a Swiss National Science Foundation Professorship under grant number PP00P1_144699. 
Table 1: Variable set and operationalisation

\begin{tabular}{|c|c|c|c|c|c|}
\hline Variable & $\begin{array}{l}\text { Expected } \\
\text { Rela- } \\
\text { tionship } \\
\end{array}$ & Description (Items) & Measurement & Sources & Cronbach $\alpha$ \\
\hline \multicolumn{6}{|c|}{ Dependent Variable } \\
\hline Learning & & $\begin{array}{l}\text { - I have learned a great deal from_source_through_mechanism_- } \\
\text { - I have greatly reduced the initial reliance on_source_since the beginning of the } \\
\text { cooperation through_mechanism_- } \\
\text { - I have understood and used the knowledge from_source_received through } \\
\text { mechanism_ }\end{array}$ & 5-point Likert & $\begin{array}{l}\text { (SIMONI } \\
\text { N, 1999) }\end{array}$ & $\begin{array}{l}0.72 \\
\text { (document) } \\
0.66 \text { (face-to- } \\
\text { face) }\end{array}$ \\
\hline \multicolumn{6}{|c|}{ Independent Variables } \\
\hline F2F contact & + & Face-to-face contact with people from the IOC and other OCOGs & $\begin{array}{l}\text { Ordinal } \\
1=\text { never; } 2=1-5 \text { days } \\
3=6-15 \text { days; } 4=16-50 \\
\text { days } 5=50+\text { days }\end{array}$ & own & $\mathrm{n} / \mathrm{a}$ \\
\hline $\begin{array}{l}\text { F2F } \\
\text { intervention }\end{array}$ & + & $\begin{array}{l}\text { Exposure to face-to-face knowledge transfer interventions: } \\
\begin{array}{cl}- & \text { workshops } \\
- & \text { observer programme } \\
- & \text { debrief }\end{array}\end{array}$ & $\begin{array}{l}\text { One point each for } \\
\text { participation in an } \\
\text { intervention }\end{array}$ & own & $\mathrm{n} / \mathrm{a}$ \\
\hline \multicolumn{6}{|c|}{ Control Variables } \\
\hline $\begin{array}{l}\text { Document } \\
\text { usage }\end{array}$ & + & $\begin{array}{l}\text { Regular usage (once a month and more often) of documents or document repository: } \\
-\quad \text { Extranet } \\
\text { - } \\
\text { - }\end{array}$ & $\begin{array}{l}\text { One point each for } \\
\text { regular usage }\end{array}$ & own & $\mathrm{n} / \mathrm{a}$ \\
\hline $\begin{array}{l}\text { Event } \\
\text { experience }\end{array}$ & $+/-$ & Previous work experience in large-scale events & Yes/No & own & $\mathrm{n} / \mathrm{a}$ \\
\hline Motivation & + & $\begin{array}{l}\text { Motivation to participate in knowledge transfer } \\
\text { - I see significant benefit in assigning time to knowledge transfer activities } \\
\text { - } \quad \text { I see significant benefit in communicating my knowledge needs to the knowledge } \\
\text { sources } \\
\text { - I see significant benefit in devoting resources to knowledge transfer activities } \\
\text { - I see significant benefit in sharing my knowledge with others }\end{array}$ & 5-point Likert & $\begin{array}{l}\text { (SZULAN } \\
\text { SKI et al., } \\
2004)\end{array}$ & 0.87 \\
\hline $\begin{array}{l}\text { Knowledge } \\
\text { sharing } \\
\text { environment }\end{array}$ & + & $\begin{array}{l}\text { Organisational preconditions for sharing knowledge: } \\
\text { - } \quad \text { My OCOG encourages the sharing of knowledge } \\
\text { - } \quad \text { My OCOG provides enough time for acquiring and processing new knowledge }\end{array}$ & 5-point Likert & own & 0.66 \\
\hline Prior expertise & $+/-$ & Prior expertise in the area of knowledge transfer & 5-point Likert & $\begin{array}{l}\text { (LEVIN } \\
\text { and }\end{array}$ & $\mathrm{n} / \mathrm{a}$ \\
\hline
\end{tabular}


- I had a good understanding of the material prior to participating in knowledge transfer through mechanism

Perishability $\quad$ How perishable is the knowledge received through a certain mechanism?
$\quad$ The knowledge I receive through mechanism_becomes quickly out of date

- The knowledge I receive through_mechanism_evolves rapidly and needs to be constantly updated

Actionable $\quad+\quad$ The knowledge received is relevant for the knowledge needs of the recipient and can

Relevance be put to action without much further adaptation.

- The knowledge I receive through _mechanism_leads to immediate progress on my current assignments

- The knowledge I receive through mechanism is directly applicable to problems I face in my work

- The knowledge I receive through_mechanism_is relevant for my work

Length of $\quad+/ \quad$ Time working in the OCOG.

Number of months.

own

$\mathrm{n} / \mathrm{a}$

Service

$\begin{array}{lll}\text { Sochi } 2014 & \text { n/a } & \text { dummy variable for respondents from the Sochi 2014 OCOG } \\ \text { Rio } 2016 & \text { n/a } & \text { dummy variable for respondents from the Rio 2016 OCOG }\end{array}$

true/false

Rio 2016

$\mathrm{n} / \mathrm{a}$ dummy variable for respondents from the Rio 2016 OCOG

true/false

the respondent designated

_mechanism_acts as a placeholder for document or informal learning interactions 
Table 2: Descriptive characteristics for sub-groups

\begin{tabular}{|c|c|c|c|c|c|c|c|c|c|}
\hline & \multicolumn{9}{|c|}{ Respondents with exposure to } \\
\hline & \multicolumn{3}{|c|}{$\begin{array}{l}\text { Document Learning } \\
(n=273)\end{array}$} & \multicolumn{3}{|c|}{$\begin{array}{l}\text { Informal Learning } \\
\qquad(\mathrm{n}=179)\end{array}$} & \multicolumn{3}{|c|}{$\begin{array}{l}\text { Both Document and } \\
\text { Informal }(n=158)\end{array}$} \\
\hline & Mean & SD & $\%$ & Mean & $\mathrm{SD}$ & $\%$ & Mean & SD & $\%$ \\
\hline Learning $^{1}$ & $3.54 \mathrm{a}$ & 0.57 & & $3.60 \mathrm{a}$ & 0.58 & & $3.57 \mathrm{a}$ & 0.54 & \\
\hline Tacitness $^{1}$ & $1.92 \mathrm{a}$ & 1.28 & & $4.22 b$ & 1.21 & & & & \\
\hline F2F contact ${ }^{1}$ & $2.72 \mathrm{a}$ & 1.38 & & $3.07 \mathrm{~b}$ & 1.34 & & $3.20 \mathrm{~b}$ & 1.30 & \\
\hline Never & & & 26.4 & & & 17.3 & & & 13.9 \\
\hline $1-5$ days & & & 21.6 & & & 17.9 & & & 16.5 \\
\hline $6-15$ days & & & 18.3 & & & 22.3 & & & 23.4 \\
\hline 16-50 days & & & 21.2 & & & 25.7 & & & 28.5 \\
\hline $50+$ days & & & 12.5 & & & 16.8 & & & 17.7 \\
\hline F2F intervention ${ }^{2}$ & $0.98 \mathrm{a}$ & 1.03 & & $1.19 \mathrm{~b}$ & 1.06 & & $1.29 \mathrm{~b}$ & 1.07 & \\
\hline Document usage & $1.57 \mathrm{a}$ & 1.14 & & $1.56 \mathrm{a}$ & 1.14 & & $1.69 \mathrm{a}$ & 1.10 & \\
\hline \multicolumn{10}{|l|}{ Event experience } \\
\hline Yes & & & $42.5 \mathrm{a}$ & & & $47.2 \mathrm{a}$ & & & $49.4 \mathrm{a}$ \\
\hline Motivation $^{1}$ & $4.13 \mathrm{a}$ & 0.62 & & $4.13 \mathrm{a}$ & 0.57 & & $4.14 \mathrm{a}$ & 0.57 & \\
\hline $\begin{array}{l}\text { Knowledge sharing } \\
\text { environment }{ }^{1}\end{array}$ & $3.96 \mathrm{a}$ & 0.76 & & $3.91 \mathrm{a}$ & 0.73 & & $3.94 \mathrm{a}$ & 0.71 & \\
\hline Prior expertise $^{1}$ & $3.23 \mathrm{a}$ & 0.98 & & $3.43 b$ & 0.95 & & $3.40 \mathrm{c}$ & 0.94 & \\
\hline Perishability $^{1}$ & -- & -- & -- & 2.86 & 0.85 & & -- & -- & -- \\
\hline Actionable & $3.62 \mathrm{a}$ & 0.64 & & $4.05 b$ & 0.65 & & $3.87 \mathrm{c}$ & 0.64 & \\
\hline Relevance $^{1}$ & & & & & & & & & \\
\hline
\end{tabular}

Where the column for the complete sample does not show values, variables were either linked to the mechanisms of learning and could not be calculated for the sample as a whole or variables were dropped in the process of data screening.

Scores in a row that do not share the same letter are significantly different at $\mathrm{p}<0.05$

1 on a scale from 1 to 5

2 on a scale from 0 to 3 
Table 3: Regression models for document and informal learning, testing propositions ( $\mathrm{P} 1)$ to $(\mathrm{P} 3)$

\begin{tabular}{|c|c|c|c|c|c|c|c|c|}
\hline & \multicolumn{2}{|c|}{$\begin{array}{l}\text { Model } 1 \\
(\mathrm{P} 2.1)\end{array}$} & \multicolumn{2}{|c|}{$\begin{array}{l}\text { Model } 2 \\
(\mathrm{P} 1)\end{array}$} & \multicolumn{2}{|c|}{$\begin{array}{c}\text { Model } 3 \\
(\mathrm{P} 2.2) \\
\end{array}$} & \multicolumn{2}{|c|}{$\begin{array}{c}\text { Model } 4 \\
(\mathrm{P} 3)\end{array}$} \\
\hline & $\begin{array}{l}\text { Document } \\
\text { Learning }\end{array}$ & $\begin{array}{l}\text { Informal } \\
\text { Learning }\end{array}$ & $\begin{array}{l}\text { Document } \\
\text { Learning }\end{array}$ & $\begin{array}{l}\text { Informal } \\
\text { Learning }\end{array}$ & $\begin{array}{l}\text { Document } \\
\text { Learning }\end{array}$ & $\begin{array}{l}\text { Informal } \\
\text { Learning }\end{array}$ & $\begin{array}{l}\text { Document } \\
\text { Learning }\end{array}$ & $\begin{array}{l}\text { Informal } \\
\text { Learning }\end{array}$ \\
\hline $\begin{array}{l}\text { F2F contact } \\
\text { F2F intervention }\end{array}$ & -0.01 & $0.16^{* *}$ & $\begin{array}{r}0.02 \\
-0.03\end{array}$ & $\begin{array}{r}0.05 \\
0.20^{* *}\end{array}$ & $\begin{array}{r}-0.07 \\
0.05\end{array}$ & $\begin{array}{r}0.01 \\
0.18^{*}\end{array}$ & $\begin{array}{r}-0.11 \\
0.10\end{array}$ & $\begin{array}{r}-0.05 \\
0.07\end{array}$ \\
\hline $\begin{array}{l}\text { Document learning } \\
\text { Informal learning }\end{array}$ & & & & & $0.26 * * *$ & $0.27 * * *$ & & \\
\hline $\begin{array}{l}\text { Document usage } \\
\text { Event experience } \\
\text { Motivation } \\
\text { Knowledge sharing } \\
\text { environment } \\
\text { Prior expertise } \\
\text { Perishability } \\
\text { Actionable } \\
\text { Relevance } \\
\text { Length of Service }\end{array}$ & & & & & & & $\begin{array}{r}0.17 * * * \\
-0.09 \\
0.17 * * * \\
0.14 * * \\
\\
0.05 \\
\mathrm{n} / \mathrm{a} \\
0.40 * * *\end{array}$ & $\begin{array}{r}-0.08 \\
0.08 \\
0.14 * \\
0.14 * \\
\\
0.03 \\
0.14 * \\
0.52 * * * \\
0.03\end{array}$ \\
\hline $\begin{array}{l}\text { Sochi } 2014 \\
\text { Rio } 2016 \\
\end{array}$ & $\begin{array}{r}0.28 * * * \\
0.12 \\
\end{array}$ & $\begin{array}{r}0.18 * * \\
0.01 \\
\end{array}$ & $\begin{array}{r}0.29 * * * \\
0.10 \\
\end{array}$ & $\begin{array}{r}0.13 \\
-0.01 \\
\end{array}$ & $\begin{array}{r}0.28 * * * \\
0.07 \\
\end{array}$ & $\begin{array}{l}0.05 \\
0.02\end{array}$ & $\begin{array}{l}0.18^{* *} \\
-0.07 \\
\end{array}$ & $\begin{array}{l}0.10 \\
0.02\end{array}$ \\
\hline $\begin{array}{l}\mathrm{F} \\
\mathrm{R}^{2} \text { (adjusted) }\end{array}$ & $\begin{array}{l}6.64 \\
0.06\end{array}$ & $\begin{array}{l}2.96^{* *} \\
0.03\end{array}$ & $\begin{array}{l}4.73 \\
0.05\end{array}$ & $\begin{array}{c}3.50 * * * \\
0.05\end{array}$ & $\begin{array}{c}6.20 * * * \\
0.14\end{array}$ & $\begin{array}{c}4.31 * * \\
0.10\end{array}$ & $\begin{array}{c}14.61 * * * \\
0.41\end{array}$ & $\begin{array}{c}7.81 * * * \\
0.36\end{array}$ \\
\hline
\end{tabular}

Standardised beta coefficients

$* * * \mathrm{p}<0.01, * * \mathrm{p}<0.05, * \mathrm{p}<0.10$ 


\section{References}

AJMAL M. M. and KOSKINEN K. U. (2008) Knowledge transfer in project-based organizations: an organizational culture perspective, Project Management Journal 39 (1), $7-15$.

AMIN A. and COHENDET P. (2004) Architectures of knowledge: firms, capabilities, and communities. Oxford University Press, Oxford.

AMIN A. and COHENDET P. (2005) Geographies of knowledge formation in firms, Industry and Innovation 12 (4), 465-86.

ASHEIM B. T. (2002) Temporary organisations and spatial embeddedness of learning and knowledge creation, Geografiska Annaler 84B (2), 111-24.

AUDRETSCH D. B. and FELDMAN M. (2003) Knowledge spillovers and the geography of innovation, in HENDERSON J. V. and THISSE J.-F. (Eds) Handbook of urban and regional economics, pp. 2713-39. North Holland, Amsterdam.

BATHELT H., MALMBERG A. and MASKELL P. (2004) Clusters and knowledge: local buzz, global pipelines and the process of knowledge creation, Progress in Human Geography 28 (1), 31-56.

BATHELT H. and SCHULDT N. (2008) Between luminaires and meat grinders: international trade fairs as temporary clusters, Regional Studies 42 (6), 853-68.

BATHELT H. and SCHULDT N. (2010) International trade fairs and global buzz, part 1: ecology of global buzz, European Planning Studies 18 (12), 1957-74.

BOSCHMA R. A. (2005) Proximity and innovation: a critical assessment, Regional Studies 39 (1), 61-74

BRESCHI S. and LISSONI F. (2003) Mobility and social networks: localised knowledge spillovers revisited, CESPRI Working Paper 142.

BRESCHI S. and LISSONI F. (2009) Mobility of skilled workers and co-invention networks: an anatomy of localized knowledge flows, Journal of Economic Geography 9 (4), 439-68. 
BROEKEL T. and BOSCHMA R. A. (2012) Knowledge networks in the Dutch aviation industry: the proximity paradox, Journal of Economic Geography 12 (2), 409-33.

COHEN W. M. and LEVINTHAL D. A. (1990) Absorptive capacity: a new perspective on learning and innovation, Administrative Science Quarterly 35 (1), 128-52.

CROSS R. and SPROULL L. (2004) More than an answer: information relationships for actionable knowledge, Organization Science 15 (4), 446-62.

DAVENPORT T. H. and PRUSAK L. (2000) Working knowledge: how organizations manage what they know. Harvard Business School Press, Cambridge, MA.

EKSTEDT E., LUNDIN R. A., SÖDERHOLM A. and WIRDENIUS H. (1999) Neoindustrial organising: renewal by action and knowledge formation in a project-intensive economy. Routledge, London.

FAULCONBRIDGE J. (2006) Stretching tacit knowledge beyond a local fix? Global spaces of learning in advertising professional service firms, Journal of Economic Geography 6, $517-40$.

FAULCONBRIDGE J., BEAVERSTOCK J. V., DERUDDER B. and WITLOX F. (2009) Corporate ecologies of business travel in professional service firms: working towards a research agenda, European Urban and Regional Studies 16 (3), 295-308.

FILIPPI M. and TORRE A. (2003) Local organisations and institutions: how can geographical proximity be activated by collective projects?, International Journal of Technology Management 26 (2-3), 386-400.

FLYVBJERG, B. and STEWART A. (2012) Olympic proportions: cost and cost overrun at the Olympics 1960 - 2012, Said Business School Working Paper.

FRAWLEY S. and ADAIR D. (Eds) (2013) Managing the Olympics. Palgrave Macmillan, Basingstoke. 
FRAWLEY S. M. and TOOHEY K. (2009) The importance of prior knowledge: the Australian Olympic Committee and the Sydney 2000 Olympic Games, Sport in Society 12 (7), 947-66.

GERTLER M. S. (2003) Tacit knowledge and the economic geography of context, or the undefinable lightness of being (there), Journal of Economic Geography 3 (1), 75-99.

GLÜCKLER J. (2008) Die Chancen der Standortspaltung: Wissensnetze im globalen Unternehmen, Geographische Zeitschrift 96 (3), 125-39.

GLÜCKLER J. and RIES M. (2012) Why being there is not enough: organized proximity in place-based philanthropy, The Service Industries Journal 32 (4), 515-29.

GRABHER G. (2002) Cool projects, boring institutions: temporary collaboration in social context, Regional Studies 36 (3), 205-14.

GRABHER G. (2004a) Learning in projects, remembering in networks, European Urban and Regional Studies 11 (2), 103-23.

GRABHER G. (2004b) Temporary architectures of learning: knowledge governance in project ecologies Organization Studies 25 (9), 1491-514.

GRABHER G. and IBERT O. (2006) Bad company? The ambiguity of personal knowledge networks, Journal of Economic Geography 6 (3), 251-71.

GRABHER G. and STARK D. (1997) Organizing diversity: evolutionary theory, network analysis and postsocialism, Regional Studies 31 (5), 533-44.

HALBWIRTH S. and TOOHEY K. (2001) The Olympic Games and knowledge management: a case study of the Sydney Organising Committee of the Olympic Games, European Sport Management Quarterly 1 (2), 91-111.

HASSINK R. and KLAERDING C. (2012) The end of the learning region as we knew it: towards learning in space, Regional Studies 46 (8), 1055-66.

HOLSAPPLE C. W. (2003) Knowledge and its attributes, in HOLSAPPLE C. W. (Ed) Handbook on knowledge management, pp. 165-88. Springer, Berlin. 
HOWELLS J. R. L. (2002) Tacit knowledge, innovation and economic geography, Urban Studies 39, 871-84.

HUBER F. (2012a) Do clusters really matter for innovation practices in Information Technology? Questioning the significance of technological knowledge spillovers, Journal of Economic Geography 12 (1), 107-26.

HUBER F. (2012b) On the role and interrelationship of spatial, social and cognitive proximity: personal knowledge relationships of R\&D workers in the Cambridge information technology cluster, Regional Studies 46 (9), 1169-82.

IBERT, O. (2004) Projects and firms as discordant complements: organisational learning in the Munich software ecology, Research Policy 33 (10), 1529-46.

IBERT, O. (2007) Towards a geography of knowledge creation: the ambivalences between 'knowledge as an object' and 'knowing in practice.'” Regional Studies 41 (1), 103-14.

IBERT O. (2010) Relational distance: sociocultural and time-spatial tensions in innovation practices, Environment and Planning A 42 (1), 187-204.

JENNINGS, W. (2012) Olympic risks. Palgrave Macmillan, Basingstoke.

JONES A. (2007) More than 'managing across borders'? The complex role of face-to-face interaction in globalizing law firms, Journal of Economic Geography 7, 223-46.

KASSENS-NOOR E. (2013) Transport legacy of the Olympic Games, 1992-2012, Journal of Urban Affairs 35(4), 393-416.

KATZ R. and ALLEN T. J. (1982) Investigating the not invented here (NIH) syndrome: a look at the performance, tenure, and communication patterns of $50 \mathrm{R} \& \mathrm{D}$ groups, $R \& D$ Management 12 (1): 7-20.

KNOBEN J. and OERLEMANS L. A. G. (2012) Configurations of inter-organizational knowledge links: does spatial embeddedness still matter?, Regional Studies 46 (8), 1005 21. 
LAM A. (2000) Tacit knowledge, organizational learning and societal institutions: an integrated framework, Organization Studies 21 (3), 487-513.

LARSEN J., URRY J. and AXHAUSEN K. (2006) Mobilities, networks, geographies. Ashgate, Aldershot.

LEVIN D. Z. and CROSS R. (2004) The strength of weak ties you can trust: the mediating role of trust in effective knowledge transfer, Management Science 50 (11), 1477-90.

MACKINNON D., CUMBERS A. and CHAPMAN K. (2002) Learning, innovation and regional development: a critical appraisal of recent debates, Progress in Human Geography 26 (3), 293-311.

MALMBERG A. and POWER D. (2005) (How) do (firms in) clusters create knowledge?, Industry and Innovation 12 (4), 409-31.

MASKELL P. and MALMBERG A. (1999) The competitiveness of firms and regions: ubiquitification and the importance of localised learning, European Urban and Regional Studies 6 (1), 9-25.

MEUSBURGER P. (2009) Spatial mobility of knowledge: a proposal for a more realistic communication model, disP 177 (2), 29-39.

MIDLER C. (1995) "Projectification" of the firm: the Renault case, Scandinavian Journal of Management 11 (4), 363-75.

MINTZBERG H. (1980) Structure in 5's: a synthesis of the research on organization design, Management Science 26 (3), 322-41.

MORGAN K. (2004) The exaggerated death of geography: learning, proximity and territorial innovation systems, Journal of Economic Geography 4 (1), 3-21.

MÜLLER M. (2014) The topological multiplicities of power: the limits of governing the Olympics, Economic Geography 90 in press, doi: 10.1111/ecge.12032 NONAKA I. (1994) A dynamic theory of organizational knowledge creation, Organization Science 5 (1), 14-37. 
NONAKA I. and VON KROGH G. (2009) Tacit knowledge and knowledge conversion: controversy and advancement in organizational knowledge creation theory, Organization Science 20 (3), 635-52.

NOOTEBOOM B. (2000) Learning and innovation in organizations and economies. Oxford University Press, Oxford.

NUNNALY J. (1978) Psychometric theory. McGraw-Hill, New York.

OINAS P. (1999) Activity-specificity in organizational learning: implications for analysing the role of proximity, GeoJournal 49 (4), 363-72.

OSTERLOH M. and FREY B. S. (2000) Motivation, knowledge transfer, and organizational forms, Organization Science 11 (5), 538-50.

PARENT M., MACDONALD D. and GOULET G. (2014) The theory and practice of knowledge management and transfer: the case of the Olympic Games, Sport Management Review in press.

POLANYI M. (1966) The logic of tacit inference, Philosophy 41, 1-18.

PONDS R., VAN OORT F. and FRENKEN K. (2007) The geographical and institutional proximity of research collaboration, Papers in Regional Science 86 (3), 423-43.

PORTER M. E. (2000) Location, competition, and economic development: local clusters in a global economy, Economic Development Quarterly 14 (1), 15-34.

PREACHER K. J. and HAYES A. F. (2004) SPSS and SAS procedures for estimating indirect effects in simple mediation models, Behavior Research Methods, Instruments, \& Computers 36 (4), 717-31.

RUTTEN R. and BOEKEMA F. (2012) From learning region to learning in a socio-spatial context, Regional Studies 46 (8), 981-92.

RYCHEN F. and ZIMMERMANN J.-B. (2008) Clusters in the global knowledge-based economy: knowledge gatekeepers and temporary proximity, Regional Studies 42 (6), 76776. 
SAXENIAN A. (1996) Regional advantage: culture and competition in Silicon Valley and Route 128. Harvard University Press, Cambridge, MA.

SCHINDLER M. and EPPLER M. J. (2003) Harvesting project knowledge: a review of project learning methods and success factors, International Journal of Project Management 21 (3), 219-28.

SIMONIN B. (1999) Ambiguity and the process of knowledge transfer in strategic alliances, Strategic Management Journal 20 (7), 595-623.

SIMONIN B. (2004) An empirical investigation of the process of knowledge transfer in international strategic alliances, Journal of International Business Studies 35 (5), 407-27.

SINGH J. (2005) Collaborative networks as determinants of knowledge diffusion patterns, Management Science 51 (5), 756-70.

STORPER M. and VENABLES A. J. (2004) Buzz: face-to-face contact and the urban economy, Journal of Economic Geography 4 (4), 351-70.

SZULANSKI G., CAPPETTA R. and JENSEN R. J. (2004) When and how trustworthiness matters: knowledge transfer and the moderating effect of causal ambiguity, Organization Science 15 (5), 600-13.

TORRE A. (2008) On the role played by temporary geographical proximity in knowledge transmission, Regional Studies 42 (6), 869-89.

TORRE A. and RALLET A. (2005) Proximity and localization, Regional Studies 39 (1), 4759.

VAN WIJK R., JANSEN J. J. P. and LYLES M. A. (2008) Inter- and intra-organizational knowledge transfer: a meta-analytic review and assessment of its antecedents and consequences, Journal of Management Studies 45 (4), 830-53.

WATSON A. (2008) Global music city: knowledge and geographical proximity in London's recorded music industry, Area 40 (1), 12-23. 
WENGER E. (1998) Communities of practice: learning, meaning, and identity. Cambridge University Press, Cambridge.

WENGER E., MCDERMOTT R. and SNYDER W. M. (2002) Cultivating communities of practice. Harvard University Press, Cambridge, MA.

WICKHAM J. and VECCHI A. (2008) Local firms and global reach: business air travel and the Irish software cluster, European Planning Studies 16 (5), 693-710.

WINK R. (2008) Gatekeepers and proximity in science-driven sectors in Europe and Asia: the case of human embryonic stem cell research, Regional Studies 42 (6), 777-91. 